AperTO - Archivio Istituzionale Open Access dell'Università di Torino

\title{
Feeding ecology of Long-eared Owls in winter: An urban perspective
}

\section{This is the author's manuscript}

Original Citation:

Availability:

This version is available http://hdl.handle.net/2318/1615299

since 2017-01-17T15:00:33Z

Published version:

DOI:10.1080/00063657.2015.1013522

Terms of use:

Open Access

Anyone can freely access the full text of works made available as "Open Access". Works made available under a Creative Commons license can be used according to the terms and conditions of said license. Use of all other works requires consent of the right holder (author or publisher) if not exempted from copyright protection by the applicable law. 
This is the author's final version of the contribution published as:

Mori, Emiliano; Bertolino, Sandro. Feeding ecology of Long-eared Owls in winter: An urban perspective. BIRD STUDY. 62 (2) pp: 257-261.

DOI: 10.1080/00063657.2015.1013522

The publisher's version is available at:

http://www.tandfonline.com/doi/pdf/10.1080/00063657.2015.1013522

When citing, please refer to the published version.

Link to this full text:

http://hdl.handle.net/2318/1615299 


\title{
Feeding ecology of Long-eared Owls in winter: an urban perspective
}

\author{
EMILIANO MORI ${ }^{1}$, SANDRO BERTOLINO $^{1 *}$
}
1. Department of Agricultural, Forest and Food Sciences, Largo Paolo Braccini 2, 10095 Grugliasco (Turin), Italy

* Email: sandro.bertolino@unito.it

\section{Suggested short title: Diet of urban Long-eared Owl}

Capsule. Although considered as a specialist predator of Microtus voles, the Long-eared Owl Asio otus may adapt its diet according to the local prey availability. We reviewed the diet of this nocturnal raptor in urban environments during the winter, using studies which reported the ingested biomass relating to different prey categories and so energy intake could be considered. The species was confirmed to feed mainly on Microtus, but in some area rats dominated the ingested biomass.

KEYWORDS: Asio otus, cities, diet, biomass, Microtus, rats

Urban areas are exponentially expanding throughout the world (McDonald 2008; Ferenc et al. 2014) and buildings are progressively replacing and fragmenting natural habitats (Turner et al. 2004; Marzluff et al. 2008). Urban parks and green patches may constitute the only natural remnants providing refuges for wildlife within anthropogenic habitats (Cornelis \& Hermy 2004; Grimm et al. 2008). Herbivorous, scavenging and omnivorous synanthropic species seem to be more successful and rapid in establishing populations in cities compared to carnivorous ones (Zalewski 1994a; Cavia et al. 2008; Ferenc et al. 2014). Nevertheless, bird species that eat rodents attracted to urban areas may be able to exploit this opportunity. The clustering of rodent species in an urban area depends on the distance from the nearest patch of natural/seminatural vegetation (Baker et al. 2003). Rats and house mice, as well as other introduced species, are often the most abundant within and in the surroundings of city centres, cemeteries, urban parks and industrial areas (Bertolino et al. 2004; Cavia et al. 2008; Martinoli et al. 2010). Once established, populations of pioneer potential prey may rapidly increase and spread, if resources are sufficient, even becoming pests (Capizzi et al. 2014). Such high concentrations of prey may attract avian predators, mainly generalist feeders (Zalewski 1994b; Dinetti \& Fraissinet 2001; Morey et al. 2007).

The Long-eared Owl Asio otus is a medium sized owl, widely distributed all over the Holarctic region: from Japan to North America throughout Eurasia and Northern Africa (BirdLife International 2012). This species typically live in open areas characterized by the presence of scattered trees used for roosting. It can colonize human environments, i.e. parklands, urban gardens and tree-lined alleys, probably helped by the availability of abandoned nests of Corvids, such as Common Magpie Pica pica (Lövy \& Riegert 2013) and Hooded Crows Corvus cornix (Koop \& Berndt 2014). Local densities of this species may be high during the winter in some urban areas (Otto 2009; Sharikov et al. 2010; Fabian \& Schimkat 2012) and up to 75-100 specimens can be observed sharing the same roost, especially during the winter (Cramp 1985; Pirovano et al. 2000; Lövy \& Riegert 2013). The rising numbers of this nocturnal raptor in urban environments (also during the breeding season) may have also been helped by population explosions of small rodents, e.g. Apodemus sylvaticus in Bruxelles (Dinetti \& Fraissinet 2001). The Long-eared Owl is considered a 
feeding specialist (Cramp 1985; Cecere \& Vicini 2001; Tome 2009), but it can change prey species too (Bertolino et al. 2001; Mori et al. 2014). Voles and mice represent the staple of its diet, but, when access to ground-dwelling rodents is denied, e.g. by snow, Long-eared Owls may extend their diet to birds (Canova 1989; Bertolino et al. 2001).

Although a review of the general diet of the Long-eared Owl has been previously carried out by Birrer (2009), in this paper we summarize the diet of the species concentrating on urban areas in order to investigate how it has adapted its diet to these environments (Sharikov et al. 2010; Lövy \& Riegert 2013). We compared the percentages of ingested biomass of different prey categories, to avoid overestimating the importance of small prey and underestimating the relevance of heavier prey, which is typical of studies based only on frequency of occurrence. We further evaluated if there was spatial or temporal variation in the diet.

The analysis was carried out by assessing studies on online databases (i.e. ISI Web of Science, Scopus, Zoological Records, Google Scholar). Search terms included all possible combinations of these words: Long-eared Owl, or Asio otus, and feeding ecology, diet, city, urban environment. Additional studies were located by analyzing the reference lists of all the collected studies and reviews, and by searching those of interest on Google Scholar. A MSc thesis (Sciolla 2002) from the University of Turin, supervised by one of the authors (SB), was also included in the analysis. We defined urban areas as a location dominated by human-built features in comparison to the areas surrounding it. We retained all studies carried out in big cities (city centers and suburbs), or concerning roost sites located at least 500 meters away from the nearest natural environment; the hunting area of the Long-eared Owl covers an average radius of about two kilometers around the roost (Cramp 1985), although home ranges in urban areas may be larger than in suburban ones (Lövy \& Riegert 2013). Only one study from the breeding period was found, therefore we carried out our analysis only for wintering owls.

We grouped the components of the diet into seven prey categories, according to those mainly represented in the analyzed studies: Arvicola spp., other Cricetidae, Rattus spp., other Muridae, other mammals, birds and insects. Food-niche breadth was measured through the standardized Levins index (Feinsinger et al. 1981): $\mathrm{B}=1 /\left(\mathrm{R}^{*} \Sigma \mathrm{p}_{\mathrm{j}}{ }^{2}\right)$, where $\mathrm{R}$ represents the number of food categories and $\mathrm{p}_{\mathrm{j}}$ is the proportion of the " $\mathrm{j}$ " food category consumed. The Czekanowski index was calculated to estimate dietary overlap for relative biomass [D $=1$ $(1 / 2)^{*}\left(\Sigma \mid\right.$ pij $\left.\left.-p_{\text {ik }} \mid\right)\right]$. Variations between the proportion of the main taxa identified and the food-niche breadth in different areas were evaluated using Spearman's rank correlation. Optimal-foraging theory predicts that a predator will feed on the most cost-effective prey to maximize its energy intake per unit time; thus, its food niche gets narrower when the main prey is more common, while it becomes broader when the main prey are scarce (Lacher et al. 1982; Pyke 1984).

A hierarchical cluster analysis was carried out to identify homogeneous subgroups of feeding aggregations (Quinn \& Keough 2002) by study areas. The similarity matrices obtained with the Percent Similarity index were entered in the cluster analyses through the UPGMA (unweighted pair-group method, using arithmetic averages) method. The output dendrogram was visually inspected to evaluate diet similarity among studies. Furthermore, differences in linear distances between roosts and the nearest natural or seminatural environment between clusters identified by this dendrogram were evaluated through the Mann-Whitney $U$-test, to verify whether owls preying mainly on different species roost at different distances from natural environments.

Eight studies included data on ingested biomass in urban areas and thus were retained for the analysis (Table 1). All these studies were carried out for a single year, apart from Martelli \& Fastelli (2013), who collected pellets for two consecutive winters; in this case we used the 
total amount of data reported by the authors, since no difference in composition of prey taxonomic category was detected between the two years of sampling. The cluster analysis identified two clusters (Fig. 1). The first group included diets very similar one to another (mean \pm SD niche overlap with pairwise comparisons: $0.73 \pm 0.10$ ) and dominated by small Cricetidae, mainly Microtus arvalis (Romanowski 1998; Laiu et al. 2002; Dziemian et al. 2012); the second one was more heterogeneous (mean niche overlap: $0.49 \pm 0.24$ ), with a prevalence of rats (Rattus spp.: 23.5\%-65.1\%). No significant difference between clades was found in the distance from the roost to the border of the urban area (Mann-Whitney $U=9 ; \mathrm{p}$ = 0.25). Other Muridae (Mus musculus and Apodemus spp.) represented the main prey category for the study by Martelli \& Fastelli (2013): these species are only secondary prey in other studies.

The ingested biomass of Rattus spp. increased in areas with a lower consumption of other Cricetidae $\left(\mathrm{r}_{\mathrm{s}}=-0.93, \mathrm{~N}=10, \mathrm{p}=0.00014\right)$. The food-niche breadth ranged from 0.22 to 0.58 (Table 1). The ingested biomass of other Cricetidae (mainly Microtus spp.) was inversely correlated with the trophic niche breadth $\left(\mathrm{r}_{s}=-0.77, \mathrm{~N}=10, \mathrm{p}=0.012\right)$; conversely, rats were positively correlated with the trophic niche breadth $\left(\mathrm{r}_{s}=0.68, \mathrm{~N}=10, \mathrm{p}=0.03\right)$.

Long-eared Owls fed mainly on Microtus, but in some areas rats dominated the ingested biomass. The food spectrum of this nocturnal raptor in natural habitats has been extensively reported, and also reviewed by Birrer (2009) who compared the frequencies of occurrence of prey classes: mammals constitute over the $90 \%$ of prey items, with voles (Microtus spp.) being the most common. Voles belonging to the genus Microtus are typical of open areas and edges of woodlands, which represent the main habitat used by Long-eared Owl for hunting (Wijnandts 1984; Cramp 1985; Lövy \& Riegert 2013). The remaining green refugia within city areas allow urban owls to hunt small mammals: usually rodents typical of open areas and/or generalist species, e.g. Microtus voles and Apodemus sylvaticus, or commensal species of the genus Rattus. We confirmed Cricetidae (mainly Microtus spp.) as the favoured prey in the diet of Long-eared Owl also in urban environments, having the highest significant negative correlation with food-niche breadth. In some study sites rats represented the most important prey, while Microtus voles were a second choice (Bezzel 1972; Laiu \& Murariu 1998; Pirovano et al. 2000; Sciolla 2002). Rats may be more profitable prey with respect to Microtus spp., because they are larger and heavier than voles (Pirovano et al. 2000). However, the cost of catching them could be high and the balance between cost and benefit has not yet been quantified. According to our analysis, Microtus species are the main prey of the Longeared Owl in urban habitats, while rats should be considered as important alternative prey.

Linear distances between roosts of owls feeding mainly on small Cricetidae and the border of the urban areas were not significantly different with respect those of owls eating mainly rats. Thus, Microtus may represent the main prey both in suburbs (Romanowski 1988) and in city centers (Laiu et al. 2002; Dziemian et al. 2012), where they can live in urban green areas, as well as rats. Only Martelli \& Fastelli (2013) found other Murids (Apodemus sylvaticus and Mus musculus) as the main prey category. The genus Arvicola also includes large species, but is poorly represented in the diet of urban Long-eared Owls, probably because they are not common in urban areas and are mainly active during the day (Pita et al. 2011). In natural environments, birds may represent an important component of the Long-eared Owl diet during the breeding period, while in winter they are probably exploited in case of deep snow cover, when access to ground-dwelling rodents is denied (Wijnandts 1984; Canova 1989; Bertolino et al. 2001). In our review, birds were significantly represented in three studies (Bezzel 1972; Laiu \& Murariu 1998; Martelli \& Fastelli 2013).

Our results provide an insight into the diet of Long-eared Owls in European cities over multiple sites. The species is generally considered as a specialist feeder, although able to exploit different food categories which are locally abundant. Microtus voles were confirmed 
to be the main prey caught by this nocturnal raptor, because these rodents are able to colonize the few remaining green areas within urban centers (Wijnandts 1984; Birrer 2009). Moreover, when predominant, they count for more than $80 \%$ of the ingested biomass: therefore, diets characterized by a high prevalence of Microtus voles are all similar to each other. Rats represent alternative prey in urban areas, but they rarely exceed $50 \%$ of the ingested biomass (see Table 1), thus resulting in more heterogeneous diets for the owls. To clarify the role of rats in the energy budget of the Long-eared Owl, further researches should compare prey importance with their availabilities in urban areas and in their surroundings.

\section{ACKNOWLEDGEMENTS}

Paul Jennings and Gilda Petri kindly revised English grammar and syntax. Two anonymous reviewers and the Editor provided us with useful comments and improvements on the first submission.

\section{REFERENCES}

Baker, P.J., Ansell, R.J., Dodds, P.A.A., Webber, C.E. \& Harris, S. 2003. Factors affecting the distribution of small mammals in an urban area. Mammal. Rev. 33: 95-100.

Bertolino, S., Ghiberti, E. \& Perrone, A. 2001. Feeding ecology of the long-eared owl (Asio otus) in northern Italy: is it a dietary specialist? Can. J. Zool. 79: 2192-2198.

Bertolino, S., Mazzoglio, P.J., Vaiana, M. \& Currado, I. 2004. Activity budget and foraging behaviour of introduced Callosciurus finlaysonii (Rodentia, Sciuridae) in Italy. $J$. Mammal. 85: 254-259.

Bezzel, E. 1972. Einige Daten zur Ernährung oberbayerischer Waldohreulen (Asio otus). Anz. Ornithol. Ges. Bayern 11: 181-184.

BirdLife International. 2012. Asio otus. In IUCN Red List of Threatened Species. Version 2012.2. Available: www.iucnredlist.org. Accessed on $16^{\text {th }}$ June 2014.

Birrer, S. 2009. Synthesis of 312 studies on the diet of the long-eared owl Asio otus. Ardea 97: 615-624.

Bux, M. 2001. Dati sull'alimentazione del gufo comune Asio otus in periodo riproduttivo in habitat urbano dell'Italia meridionale. Avocetta 25: 161.

Canova, L. 1989. Influence of snow cover on prey selection by long-eared owls Asio otus. Ethol. Ecol. Evol. 1:367-372.

Capizzi, D., Bertolino, S., Mortelliti, A. 2014. Rating the rat: global patterns and research priorities in impacts and management of rodent pests. Mammal. Rev. 44: 148-161.

Cavia, R., Rubèn Cueto, G. \& Suàrez, O.V. 2008. Changes in rodent communities according to the landscape structure in an urban ecosystem. Landsc. Urb. Plan. 90: 11-19.

Cecere, F. \& Vicini, G. 2000. Micromammals in the diet of the long eared owl (Asio otus) at the W.W.F.'s Oasi San Giuliano (Matera, Southern Italy). Hystrix, It. J. Mamm. 11: 47-53.

Cornelis, J. \& Hermy, M. 2004. Biodiversity relationships in urban and suburban parks in Flanders. Landsc. Urb. Plan. 69: 385-401.

Cramp, S. 1985. (ed.) The Birds of the Western Palearctic. Vol 4. Oxford University Press, Oxford, UK.

Dinetti, M. \& Fraissinet, M. 2001. Ornitologia urbana. Calderini Edagricole, Milano, Italy.

Duettmann, H., Suhren, I., Duettmann, J. \& Bergmann, H. 2009. Vergleichende Untersuchung zum Nahrungserwerb von Waldohreule (Asio otus) and Schleiereule (Tyto alba) im Stadtrandgebiet von Osnabrueck (Niedersachsen). Osnabruecker Naturwissenschaftliche Mitteilungen 36: 47-53.

Dziemian, S., Piłacińska, B. \& Pitucha, G. 2012. Winter diet composition of urban longeared owls (Asio otus) in Rzeszòw (SE Poland). Biol. Lett. 49: 107-114. 
Fabian, K. \& Schimkat, J. 2012. Waldohreulen Asio otus in der Grossstadt - Die Besiedlung des Stadtgebiets von Dresden. Vogelwelt 133: 77-88.

Feinsinger, P., Spears, E.E. \& Poole, R.W. 1981. A simple measure of niche breadth. Ecology 62: 27-32.

Ferenc, M., Sedlàcek, O., Fuchs, R., Dinetti, M., Fraissinet, M. \& Storch, D. 2014. Are cities different? Patterns of species richness and beta diversity of urban bird communities and regional species assemblages in Europe. Glob. Ecol. Biogeogr. 23: 479-489.

Grimm, N.B., Faeth, S.H., Golubiewski, N.E., Redman, C.L., Wu, J., Bai, X. \& Briggs, J.M. 2008. Global change and the ecology of cities. Science 319: 756-760.

Kiat, Y., Perlman, G., Balaban, A., Leshem, Y., Izhaki, I. \& Charter, M. 2008. Feeding specialization of urban long-eared owls, Asio otus (Linnaeus, 1758), in Jerusalem, Israel. Zool. Middle East 43: 49-54.

Koop, B. \& Berndt, R.K. 2014. Vogelwelt Schleswig-Holsteins. Bd. 7: Zweiter Brutvogelatlas. Wachholtz Editions, Berlin, Germany.

Lacher, T.E., Willig, M.R. \& Mares, M.A. 1982. Food preference as a function of resource abundance with multiple prey types: an experimental analysis of optimal foraging theory. Am. Nat. 120: 297-316.

Laiu, L. \& Murariu, D. 1998. The food of the long-eared owl (Asio otus otus L.) (Aves: Strigiformes) in wintering conditions of the urban environment in Romania. Trav. Mus. Nation. Hist. Nat. "Grigore Antipa” 40: 413-430.

Laiu, L., Pasol, P., Feneru, F. \& Murariu, D. 2002. The analysis of the winter food structure in Asio otus otus L. (Aves: Strigiformes) from Bacau and Iasi towns - Moldavia, Romania. Trav. Mus. Nation. Hist. Nat. "Grigore Antipa” 44: 423-430.

Lövy, M. \& Riegert, J. 2013. Home range and land use of urban long-eared owls. Condor 115: 551-557.

Maccarone, A.D. \& Janzen, P. 2005. Winter diet of Long-eared Owls (Asio otus) at an urban roost in Wichita, Kansas. Trans. Kansas Ac. Sci. 108: 116-120.

Martelli, C., \& Fastelli, P. 2013. Svernamento e dieta del gufo comune Asio otus nella città di Grosseto. Gli Uccelli d'Italia 38: 85-91.

Martinoli, A., Bertolino, S., Preatoni, D.G., Balduzzi, A., Marsan, A., Genovesi, P., Tosi, G. \& Wauters, L.A. 2010. Headcount 2010: the multiplication of the grey squirrel introduced in Italy. Hystrix, It. J. Mammal. 21: 127-136.

Marzluff, J.M., Shulenberger, E., Endlicher, W., Alberti, M., Bradley, G., ZumBrunnen, C. \& Simon, U. 2008. Urban ecology: an international perspective on the interaction between humans and nature. Springer, New York, USA

Mastrorilli, M., Barbagallo, A. \& Bassi, E. 1999. Dati sulla nicchia trofica invernale del gufo comune Asio otus in provincia di Bergamo. Avocetta 23: 54.

McDonald, R.I. 2008. Global urbanization: can ecologists identify a sustainable way forward? Front. Ecol. Envir. 6: 99-104.

Meritt, D.A. Jr. 2011. The diet of long-eared owls (Asio otus) in an urban park. Trans. Illinois State Ac. Sci. 104: 1-4.

Morey, P.S., Gese, E.M. \& Gehrt, S. 2007. Spatial and temporal variation in the diet of coyotes in the Chicago metropolitan area. Am. Midl. Nat. 158: 147-161.

Mori, E., Menchetti, M. \& Dartora, F. 2014. Evidences of the carrion consumption behaviour in the long-eared owl Asio otus (Linnaeus, 1758) (Aves: Strigiformes: Strigidae). Ital. J. Zool. 81: 471-475.

Otto, W. 2009. Sehr frühe Brut und Burtverbreitung der Waldohreule Asio otus in Berlin. Berliner Ornithol. Ber. 19: 34-44. 
Pirovano, A., Rubolini, D., Brambilla, S. \& Ferrari, N. 2000. Winter diet of urban roosting long-eared owls Asio otus in Northern Italy: the importance of the brown rat Rattus norvegicus. Bird Study 47: 242-244.

Pita, R., Mira, A., Beja, P. 2011. Circadian activity rhythms in relation to season, sex and interspecific interactions in two Mediterranean voles. Anim. Behav. 81: 1023-1030.

Pyke, G.H. 1984. Optimal foraging theory: a critical review. Annu. Rev. Ecol. Syst. 15: 523575.

Quinn G.P. \& Keough, M.J. 2002. Experimental design and data analysis for biologists. Cambridge University Press, Cambridge, UK.

Riegert, J., Lövy, M. \& Fainovà, D. 2009. Diet composition of common kestrels Falco tinnunculus and long-eared owls Asio otus coexisting in an urban environment. Ornis Fennica 86: 123-130.

Romanowski, J. 1988. Trophic ecology of Asio otus (L.) and Athene noctua (Scop.) in the suburbs of Warsaw. Pol. Ecol. Stud. 14: 223-234.

Sciolla, M.G. 2002. La dieta del gufo comune (Asio otus) in ambiente urbano. Dissertation, University of Turin, Turin, Italy.

Seçkin, S. \& Coşkun, Y. 2006. Mammalian remains in the pellets of long-eared owls (Asio otus) in Diyarbakir Province. Turk. J. Zool. 30: 271-278.

Sharikov, A.V., Volkov, S.V., Ivanov, M.N. \& Basova, V.B. 2010. Formation of aggregated settlements as an expression of synanthropization of long-eared owl (Asio otus L.). Russ. J. Zool. 41: 44-50.

Sharikov, A. \& Makarova, T. 2014. Weather conditions explain variation in the diet of longeared owl at winter roost in central part of European Russia. Ornis Fennica 91: in press.

Suzuki, K. \& Yanagawa, H. 2011. Small mammals preyed on by long-eared owls, Asio otus, wintering in an urban riparian zone. Mammal. Sci. 51: 315-319

Tome, D. 2009. Changes in the diet of long-eared owl Asio otus: seasonal patterns of dependence on vole abundance. Ardeola 56:49-56.

Turner, W.R., Nakamura, T. \& Dinetti, M. 2004. Global urbanization and the separation of humans from nature. BioScience 54: 585-590.

Wijnandts, H. 1984. Ecological energetics of the long-eared owl (Asio otus). Ardea 72: 1-92.

Yuan, L., Bao, W., Wang, A. \& Zhang, L. 2010. Bat components in the food of wintering Long-eared owls in Beijing. Scientia Silvae Sinicae 46: 109-112 (in Chinese with English summary).

Zalewski, A. 1994a. A comparative study of breeding bird populations and associated landscape character, Torun, Poland. Landsc. Urb. Plan. 29: 31-34.

Zalewski, A. 1994b. Diet of urban and suburban tawny owls (Strix aluco) in the breeding season. J. Rapt. Res. 28: 246-252.

Zhang, L. J., Wang, A.-m., Bao, W.-d. \& Li, X.-J. 2009. Food composition of wintering long-eared owls (Asio otus) in different habitats in Beijing. Chin. J. Ecol. 28: 1664-1667 (in Chinese with English Summary). 
Table 1. Prey biomass and Levins index of the diet of Asio otus in the studies included in the analysis. The number of prey individuals is given in brackets, near the name of the study. CC, city centre; SU, suburb.

\begin{tabular}{|c|c|c|c|c|c|c|c|c|c|c|}
\hline \multirow[t]{2}{*}{ Study (number of prey) } & \multirow[t]{2}{*}{ Country } & \multirow{2}{*}{$\begin{array}{c}\begin{array}{c}\text { Type of } \\
\text { study site }\end{array} \\
\end{array}$} & \multicolumn{7}{|c|}{ Biomass (\%) } & \multirow{2}{*}{$\begin{array}{c}\text { Levins index } \\
\text { (B) }\end{array}$} \\
\hline & & & $\begin{array}{c}\text { Arvicola } \\
\text { spp. }\end{array}$ & $\begin{array}{c}\text { Other } \\
\text { Cricetidae }\end{array}$ & $\begin{array}{c}\text { Rattus } \\
\text { spp. }\end{array}$ & $\begin{array}{c}\text { Other } \\
\text { Muridae }\end{array}$ & $\begin{array}{c}\text { Other } \\
\text { Mammals }\end{array}$ & Birds & Insects & \\
\hline Martelli \& Fastelli 2013 (159) & Italy & $\mathrm{CC}$ & 0.0 & 0.0 & 5.1 & 73.7 & 0.0 & 21.1 & 0.1 & 0.24 \\
\hline Pirovano et al. 2000 (2760) & Italy & $\mathrm{CC}$ & 1.1 & 9.5 & 65.1 & 20.0 & 0.3 & 4.0 & 0.0 & 0.35 \\
\hline Laiu \& Morariu 1998 (1025) & Romania & $\mathrm{CC}$ & 0.0 & 4.7 & 53.2 & 19.5 & 0.0 & 22.6 & 0.0 & 0.45 \\
\hline Sciolla $2002(580)$ & Italy & SU & 2.2 & 32.9 & 27.3 & 34.9 & 0.4 & 2.3 & 0.0 & 0.55 \\
\hline Bezzel 1972 (334) & Germany & $\mathrm{CC}$ & 2.0 & 33.0 & 23.5 & 11.0 & 0.5 & 30.0 & 0.0 & 0.54 \\
\hline Laiu et al. 2002 (741) & Romania & $\mathrm{CC}$ & 0.0 & 62.0 & 0.0 & 32.8 & 0.2 & 5.0 & 0.0 & 0.29 \\
\hline Romanowski 1988 (1113) & Poland & SU & 0.4 & 86.3 & 0.4 & 6.7 & 0.1 & 6.1 & 0.0 & 0.22 \\
\hline Dziemian et al. 2012 (1976) & Poland & $\mathrm{CC}$ & 2.4 & 81.5 & 0.0 & 15.79 & 0.05 & 0.25 & 0.01 & 0.24 \\
\hline
\end{tabular}




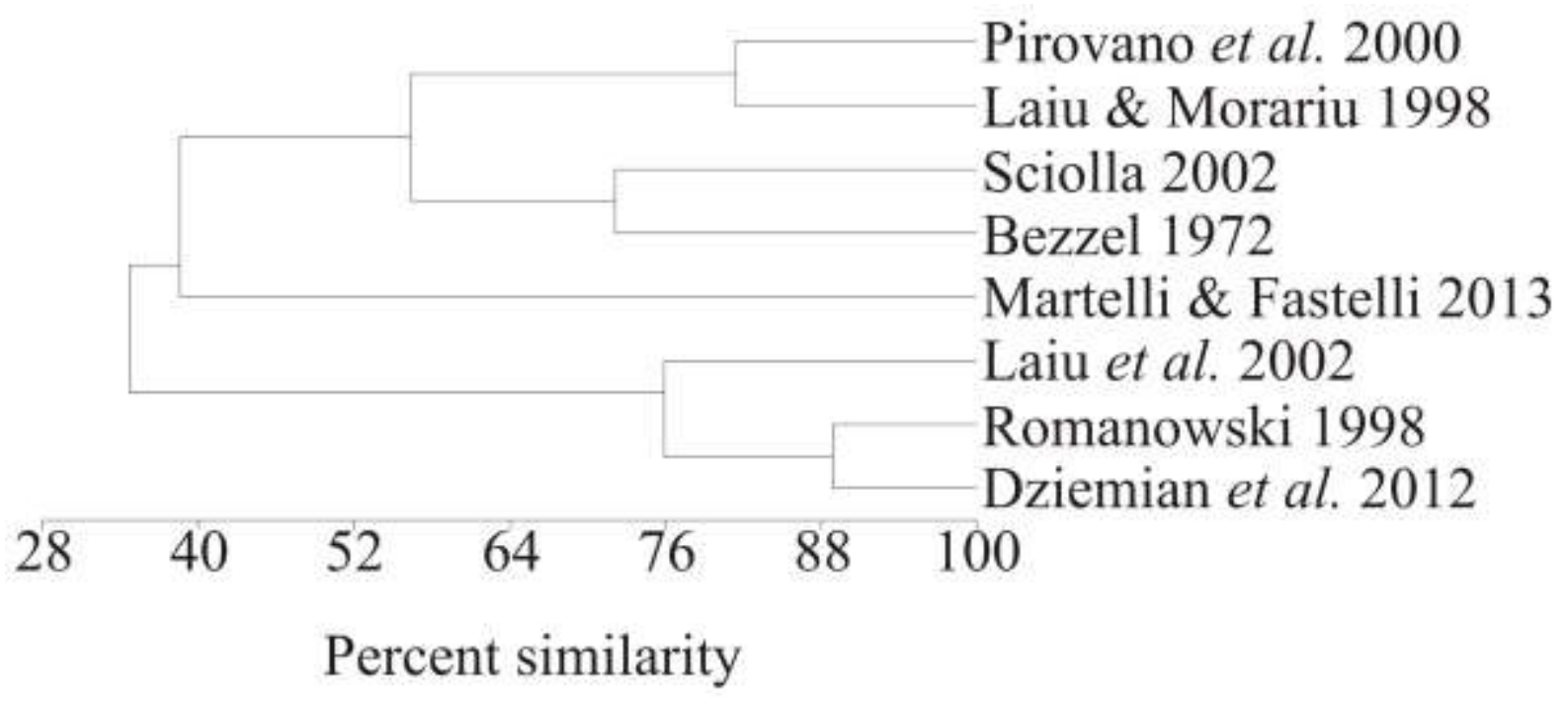

Figure 1 Dendrogram resulted from cluster analysis using the percentage similarity of relative biomass frequency and the UPGMA method, with prey grouped into seven main categories. 